\title{
MYŚL POLITYCZNA - ZWIERCIADŁO SPOŁECZNYCH ASPIRACJI ORAZ PRAGNIEŃ. MOŻLIWOŚCI (ORAZ KORZYŚCI) BADAWCZE, OGRANICZENIA, BARIERY, PUŁAPKI
}

\begin{abstract}
Dla historyka powodem do prowadzenia badań dotyczących myśli politycznej jest przede wszystkim próba rozszerzenia zakresu pytań, które, gdy się na nie odpowie, pozwolą, aby najważniejsze zjawiska i procesy z przeszłości mogły zostać wyjaśnione dokładniej i z większą precyzją. Jeśli stwierdzimy, jak ludzie myśleli, zrozumiemy, w jaki sposób zachowywali się i dlaczego. Mankamentem powszechnie spotykanym podczas wielu prób rekonstruowania przeszłości jest pozornie oczywiste, ale mimo to błędne założenie, że podstawowa racjonalność pozostaje na stałym poziomie, a ludzie żyjący w dawnych czasach myśleli podobnie do tego, jak ma to miejsce dzisiaj. Jest to szczególnie powszechne w historii współczesnej, ze względu na wrażenie, że czasy, które staramy się opisywać są zasadniczo czasami współczesnymi. Jednak to wrażenie może być błędne: nawet zestaw terminów i wyrażeń używanych w codziennej komunikacji zmienia się co 10-15 lat. W przypadku daleko idących zmian w sytuacji politycznej i społecznej sprawy komplikują się jeszcze bardziej, a prawdopodobieństwo błędu popełnianego przez badacza wzrasta znacząco.

Jest to szczególnie prawdziwe podczas próby rekonstrukcji debaty publicznej. Nawet posiadając ślady materialne takiej debaty do naszej dyspozycji (korespondencja, pamiętniki, programy partii politycznych, polemiki, a co najważniejsze prasę) możemy błędnie zrozumieć ich przesłanie (lub przynajmniej nie zrozumieć go całkowicie) jak tylko traktujemy je jako wyraz poglądów oderwanych od kontekstu lub ich aktualnej sytuacji. Interpretacje wystąpień publicznych ( $w$ tym komentarze) polityków i ideologów są szczególnie na to narażone. Stwierdzenie, że dla polityka, słowa są narzędziem działania, a nie dzielenia się swoimi przemyśleniami jest truizmem. Sytuacja towarzysząca działaniom polityka tworzy tło do słów wypowiedzianych publicznie. W wielu przypadkach decydującymi czynnikami nie są tylko treść, ale również forma wypowiedzi. A te były (i nadal są) inne. Polityk czasem komentuje sytuację otwarcie, czasami z aluzją, a czasem wierząc, że "historia magistra vitae est", poprzez wzmiankę o ostatnich wydarzeniach. Jednak w tym ostatnim przypadku to obecna sytuacja, a nie odległa przeszłość, jest zwykle używana jako odniesienie do interpretacji.

Jest oczywiste, że wszystkie te niuanse muszą być brane pod uwagę podczas rekonstrukcji poglądów bądź osoby, bądź społeczności. W przypadku społeczności ważne jest, aby opisać główny nurt poglądów, jak również skrajności, biorąc pod uwagę ich ewolucję i wszystkie indywidualne różnice, które odzwierciedlają pomysły, które ulegały zmianom. Błędem popełnianym w wielu badaniach na ten temat jest „uśrednienie" wszystkich poglądów występujących w badanym środowisku poprzez zacieranie różnic i
\end{abstract}

${ }^{1}$ Prof. dr hab. Krzysztof Kawalec, Uniwersytet Wrocławski, Instytut Historyczny, IPN (delegatura Opolska), e-mail: k.kawalec.1954@gmail.com 
pokazanie jak elementy doktryny są połączone ze sobą, a nie, jak były one związane z ich otoczeniem oraz zmieniającą się sytuacją polityczną.

Słowa kluczowe: myśl polityczna, historia najnowsza, debata publiczna, społeczne aspiracji i pragnienia, trudności badawcze.

\section{WSTEP}

„Myśl polityczna - pisał w połowie lat siedemdziesiątych Henryk Zieliński - stanowi jeden z najczulszych sejsmografów, rejestrujących procesy ewolucji i przemian w życiu narodu. Jednocześnie jest fenomenem, który w sposób szczególnie wyrazisty odzwierciedla trwanie i ciągłość jego historycznej indywidualności w gronie innych narodów. Z tych względów poznanie dziejów polskiej myśli politycznej, zwłaszcza XIX i XX w., wydaje się być rzeczą ze wszech miar godną wysiłku badawczego nie tylko z uwagi na korzyści naukowe, ale także dlatego, iż jest to niezbędną przesłanka lepszego zrozumienia teraźniejszości"2. Warto przypomnieć tę wypowiedź -powstałą w zupełnie innych czasach, prawie 40 lat temu - ze względu na to, że w skondensowanej formie wskazuje sens penetracji badawczej zjawisk przemijających, ulotnych, stanowiących - jak zapis rysika sejsmografu - zaledwie echo oddziaływania całego zespołu bardzo rozmaitych przyczyn, często odległych od miejsca obserwacji obserwatora.

Historyk jest $\mathrm{w}$ nieco innej sytuacji od badacza interesującego się ruchami skorupy ziemskiej. Oprócz śledzenia „sejsmografu” w postaci zapisanych oczekiwań, aspiracji i planów, ma możliwość dotarcia do podstawowej dokumentacji, jaką stanowią materiały wytworzone przez kluczowe urzędy. Wszakże -abstrahując od szans przechowania się owej dokumentacji w całości- możliwość pełniejszego z niej skorzystania pojawia się na ogół dość późno, gdy kluczowe postacie już nie żyją. Ryzyko błędu, polegającego na mimowolnym przypisywaniu postaciom uformowanym w świecie systemu wartości odrębnym od naszego, choć podobnego do tego, którym my się kierujemy (bądź co najmniej kryteriów racjonalności, podobnych do naszych), można starać się zmniejszyć, badając różne przekazy o charakterze prywatnym, przede wszystkim korespondencję oraz pisane na gorąco wspomnienia -niestetynie na wszystkie pytania znajdzie się odpowiedź. Badanie obiegu idei pozwala w pewnym stopniu zapełnić tę lukę - lukę istotną, gdyż bez poznania świata wartości, motywacji, wreszcie wiedzy uczestników wydarzeń o otaczającym ich świecie nie zrozumiemy, czym się kierowali, podejmując decyzje, także te najważniejsze, o zasadniczym znaczeniu dla reprezentowanej grupy czy nawet ogólnospołecznym.

Próbując dokonać rekonstrukcji poglądów postaci oraz środowisk politycznych, historyk dąży więc przede wszystkim do pełniejszego wyjaśnienia kluczowych procesów i zjawisk. Rekonstrukcja enuncjacji oraz poglądów tworzących debatę publiczną stanowi odrębne zagadnienie ze względu na specyfikę przekazów oraz właściwości źródeł (najczęściej prasowych), zasadniczo jednak dokonuje się w związku z analizą kwestii związanych zarówno ze stanem świadomości (świadomość polityczna oraz społeczna ${ }^{3}$, kultura polityczna, obyczajowość), jak i należących do tradycyjnej historii politycznej (mechanizmy kreowania autorytetu, podejmowania decyzji, modele przywództwa itp.).Od enuncjacji i poglądów dla historyków bardziej interesujące są ich skutki, analiza zaś

${ }^{2}$ H. Zieliński, Stowo wstępne, [w:]Polska myśl polityczna XIX $i$ XX wieku,t.1:Polska i jej sąsiedzi, red. H.Zieliński, Wrocław 1975, s.5.

${ }^{3}$ Patrz R.Wapiński, Świadomość polityczna w II Rzeczypospolitej, Łódź 1989. 
poglądów sprowadza się dla nich w dużym stopniu do zasygnalizowania głównych trendów oraz zwrócenia uwagi na kierunki dokonujących się zmian, w powiązaniu z przeobrażeniami zachodzącymi się w obrębie badanej zbiorowości, a także jej właściwościami (zwłaszcza podziałami na frakcje, podziałami pokoleniowymi, a także stopniem tolerancji w obrębie poszczególnych frakcji dla różnic poglądów).

O ile można by zatem powiedzieć, że w badaniach myśli politycznej przyświecające historykom cele są raczej utylitarne, to trzeba zaznaczyć, że badana materia nie jest czymś marginalnym. Tocząca się w przestrzeni publicznej debata jest w równej mierze odbiciem wielu złożonych zjawisk i procesów, jak i stanowi wartość samą w sobie. Odzwierciedla właściwości politycznej kultury, cechy elit, a także właściwości zbiorowego dziedzictwa, formującego zarówno owe elity, jak i odbiorców kierowanego do nich przekazu. Można ją także traktować jako element procesu demokratyzacji społeczeństwa, w coraz większym stopniu uczestniczącego w poczynaniach oraz decyzjach istotnych dla jego egzystencji oraz przyszłości. To jest niewątpliwie wartość, bez względu na to, że jakość tej debaty przedstawia się nieraz różnie, że przekaz kierowany do masowego odbiorcy ulega spłyceniu; bywa także, że zamiast istotnych treści zawiera on rozmaite tematy zastępcze.

O kształcie owych „treści istotnych” decydują potrzeby zbiorowości. Wwypadku Polski, poczynając od początków XVIII stulecia, na pierwszy plan wysuwały się kwestie związane z utrzymaniem suwerenności (bądź próbami jej odzyskania w warunkach obcego panowania). Kojarzone z prądami dominującymi w obrębie świata zachodniego, trwale postrzeganego $\mathrm{w}$ Polsce jako punkt odniesienia, wyraziły się one w przekonaniu o szczególnej roli idei wolnościowych w dziejach narodu, jak i o jego przynależności do kultury łacińskiej (nie zaś słowiańskich). Pociągając za sobą skutki zarówno w relacjach z sąsiadami, jak i wewnętrznych, budziły one namiętne spory, ale i wyciskały piętno na zachowaniach zbiorowych. Inaczej niż dzieje się to w odniesieniu do wskazówki sejsmografu, rejestrującej jedynie procesy dokonujące się gdzieś w głębi - zaznaczające się w skali masowej przekonania wywierają wpływ na losy zbiorowości, niekiedy znaczny, bywa, że nawet dominujący.

Uczynienie publicznej debaty przedmiotem badań, analiza zaznaczającej się w jej obrębie treści, zarówno dominujących, jak i występujących instrumentalnie, śledzenie jej ewolucji, określanie charakteru zmian poszczególnych jej elementów, ich dynamiki, a także próby określenia możliwych ich przyczyn wydają się oczywiste w świetle zarówno wagi problematyki, jak i dodatkowych korzyści związanych z pełniejszym rozumieniem zachowań ludzi żyjących w odległych od naszych czasach. Jest to jednak jednocześnie materia bardzo subtelna i złożona, co sprawia, że w wielu wypadkach formułowane wnioski będą jedynie hipotezami o różnym stopniu prawdopodobieństwa. Barierę tworzy w tym wypadku niemożność przekroczenia bariery czasu oraz swobodne posługiwanie się kategoriami i pojęciami, należącymi do przeszłości. Skądinąd samo zbliżanie się do tej bariery tworzy problemy, stawiając historyka pomiędzy Scyllą nadmiernego utożsamienia się z przedmiotem badań a Charybdą arbitralnego jego opisu za pomocą pojęć i kategorii, które dla badanego środowiska byłyby zupełnie niezrozumiałe ${ }^{4}$. Występujące tu

${ }^{4}$ Pomijam tu jako odrębny problem wypadki stronniczości badaczy, manipulujących danymi zawartymi w przekazie źródłowym przez tendencyjny dobór treści, a bywa że dzieje się gorzej dochodzi do dezinformacji czytelnika co do istotnej ich treści. Interesujące przykłady podobnych praktyk - niestety wykaz ogranicza się do naukowych celebrytów - zawiera witryna 
zagrożenia i pułapki najwygodniej przedstawić na przykładzie konkretnych przypadków, ilustrujących związki między sferą faktów i zdarzeń a sferą świadomości.

\section{RACJONALNE-NIERACJONALNE}

W głośnej powieści Emila Zoli Nana oprawę agonii bohaterki, oszpeconej, umierającej na ospę, tworzyły radosne okrzyki tłumu, cieszącego się z nadciągającej wojny z Prusami (1870), nieprzeczuwającego bliskiej katastrofy. Nana stanowiła alegorię Francji; odrażające krosty pokrywające ciało umierającej bohaterki - sugerować mogłyrozkład mieszczańskiego świata, zdemoralizowanego, rekompensującego poczucie słabości tromtadracją.

„W portki robią, zobaczysz, Antoni, Julek w portki robią, trzęsą się ze strachu” - tak w gronie skamandrytów komentował rozlepione w końcu sierpnia 1939 r. plakaty mobilizacyjne komunista, Władysław Daszewski ${ }^{5} \ldots$ „Myślę, że mało kto wątpi tutaj, że Polska nie podjęłaby walki dla poparcia decyzji wyrażonej przez Becka"- komentował kilka miesięcy wcześniej w sporządzanym raporcie znane przemówienie ministra spraw zagranicznych z 5 maja 1939 r. amerykański attache wojskowy, mjr William H. Colbern. „Teraz nerwy ich są w dobrym stanie i szczerze podziwiam pewność, z jaką radzą sobie z tą sytuacją. Okaże się, czy wytrzymają przez okres kilku miesięcy, czy też nie. Mając w pamięci przykład Czech, muszę powiedzieć, że nie oczekuję tutaj podobnego

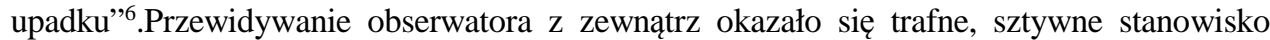
władz państwowych w obliczu zagrożenia wytrzymało próbę kolejnych miesięcy ${ }^{7}$, przy pełnym wsparciu ze strony opinii publicznej, także opozycyjnej wobec rządu, ale nie wobec prowadzonej przezeń polityki obrony suwerenności państwa. Wyjątki były bardzo nieliczne; przekonaniem, że podjęta w 1939 r. decyzja była słuszna, nie zachwiała ani klęska wojenna, ani ujawniające się z czasem dalekosiężne (widoczne także w okresie powojennym) jej skutki - zwłaszcza to, że oznaczała ona trwałą utratę suwerenności oraz degradację cywilizacyjną. Jeśli zatem w pisanych po latach przekazach pamiętnikarskich pojawiały się wątpliwości i zarzuty, to dotyczyły one nie obarczonej wielkim ryzykiem decyzji, ale wcześniejszych przygotowań wojennych, postrzeganych jako niedostateczne. Na polityce poszukiwania oparcia w krajach zachodnich położyła się cieniem ich bierność w 1939 r., potem zaś Jałta. Trudno spekulować, w jakiej mierze rozczarowanie do wojennych sojuszników Polski mogło sprzyjać recepcji forsowanej przez propagandę PRL tezy o naturalności związku $\mathrm{z}$ ZSRR.Poza środowiskami komunistycznymi podobny pogląd ${ }^{8}$ szerzej się nie przyjął.

„Kompromitacje. Przypadki słabości ludzkich” (http://kompromitacje.blogspot.com/dostęp: 3.11.2014)

${ }^{5}$ Wedle relacji A. Wata, Mój wiek. Pamiętnik mówiony. Czesść pierwsza, rozmowy prowadził i przedmową opatrzył Cz. Miłosz, Warszawa 1990, s. 230.

${ }^{6}$ W.H. Colbern, Polska. Styczeń -sierpień 1939. Analizy i prognozy. Komentarze do wydarzeń attache wojskowego ambasady USA w Warszawie, Warszawa 1986, s.55.

${ }^{7} \mathrm{~W}$ świetle współczesnego stanu badań (Stanisław Żerko, Marek Kornat) wiadomo, że grupa rządząca była zdecydowana przeciwstawić się Niemcom, wybór zaś postawy sztywnej wiązał się między innymi z analizami mechanizmu załamania się Czechosłowacji. Uznano, że elastyczność może zachęcić agresora do stopniowania nacisku, sojusznikom zaś może ułatwić uchylanie się od spełnienia zobowiązań.

${ }^{8} \mathrm{Tu}$ znakiem czasu była naturalnie książka Aleksandra Bocheńskiego, Dzieje głupoty w Polsce. Pamflety dziejopisarskie, Warszawa 1947. 
Zmiana optyki przyszła $\mathrm{z}$ czasem, była związana $\mathrm{z}$ przemianą pokoleniową oraz degradacją skali aspiracji zbiorowych. W spektakularny sposób kruszenie się mitu „Polandfirst to fight" dokonuje się na naszych oczach, w dodatku - czego trudno nie uznać za znak czasu - dzieje się to w sposób szczególny w obrębie środowisk deklarujących przywiązanie do narodowej tradycji. Abstrahując od merytorycznych walorów dowodzenia opartego na przewidywaniach niedoszłej przeszłości, nie ma powodów, by nie traktować publicystyki Piotra Zychowicza, a ostatnio także Rafała Ziemkiewicza ${ }^{9}$ jako ważnego sygnału, produktu dokonującej się na naszych oczach ewolucji świata wartości, a dodatkowo ilustracji zmieniających się kryteriów racjonalności.

Aleksander Hertz dowodził, że racjonalne zachowania są w ogóle rzadkością, w czasach zaś wielkich panik zanikają zupełnie ${ }^{10}$. Odnosząc tę uwagę do zachowańz wiosny i lata 1939 r., warto pamiętać, że ów irracjonalizm mógł się przecież ujawnić na przykład w postaci paraliżującego lęku. Przekonanie, że w obliczu zagrożenia integralności terytorialnej i suwerenności państwo powinno się bronić zapewne wyrastało z doświadczeń pokoleń, dla których własne państwo było niedościgłym marzeniem; w co najmniej równej jednak mierze wyrażało optykę społeczeństwa o dużej dynamice, demograficznie młodego, ulegającemu właściwemu młodości przekonaniu o własnej niezniszczalności ${ }^{11}$. Dla odmiany pogląd, że suwerenność jest wartością względną, którą należy gospodarować zgodnie z rachunkiem sił, przy ograniczeniu ryzyka związanego z możliwością narażenia się silniejszemu - jest zupełnie zrozumiały w obrębie społeczeństwa po przejściach, starzejącego się, a przy tym coraz dalszego od tendencji do idealizowania własnego państwa. Na wpływ doświadczeń z niesuwerenną państwowością komunistyczną, po roku 1989 nałożyły się frustracje $\mathrm{z}$ powodu jakości struktur suwerennych wprawdzie, ale działających w sposób wysoce niedoskonały.

Traumatyczne doświadczenia, związane ze zmianą realiów zewnętrznych oraz przemianami pokoleniowymi, doprowadziły do zmiany świata pojęć ${ }^{12}$. Większość przesłanek dla takowej działała z całą siłą przez cały okres powojenny i gdyby przed 1989 r. istniały warunki do prowadzenia wewnętrznej debaty, charakter zaś państwowości zideologizowanej, kultywującej biedę, a przy tym uzależnionej od zewnętrznego ośrodka dyspozycji- nie sprzyjał idealizowaniu państwowości przedwojennej, próby podważania

${ }^{9}$ Odnosi się to przede wszystkim do twórczości Ziemkiewicza, posiadającego dużą wiedzę i kulturę historyczną. Warto zestawić dwie wizje alternatywnego biegu wydarzeń jego autorstwa: tej sprzed kilkunastu lat, zawartej w noweli Żadnych marzeń, oraz wydanej ostatnio książki Jakie piękne samobójstwo.

${ }^{10}$ A. Hertz, Żydzi w kulturze polskiej, Paryż 1961, s. 209-210.

${ }^{11}$ Przyjmując tego rodzaju założenie jako rodzaj roboczej hipotezy, można założyć, że nie było przypadkiem, że wątpliwości wobec tego rodzaju optyki ujawniły się akurat w obrębie środowisk konserwatywnych - czyli poza zasięgiem mających poczucie własnej siły ruchów masowych. Mam tu na myśli zarówno rozrachunkową publicystykę Stanisława Mackiewicza-Cata, jak i dzieło rozliczającego się $\mathrm{z}$ mitem suwerenności Aleksandra Bocheńskiego - powstałe co prawda w specyficznych warunkach, po Jałcie.

${ }^{12}$ Nawet jeśli uznać za zbyt daleko idący pogląd Ryszarda Legutki o zerwaniu historycznej ciągłości (Esej o duszypolskiej, Kraków 2008), to jednak skala zmian jest bardzo wielka, o wiele większa, niż wynikałoby $\mathrm{z}$ deklaracji. W pewnejmierze zapowiedzią tej sytuacji po 1989 r. było fiasko podejmowanych prób restytucji tradycyjnych nurtów ideowo-politycznych. 
kluczowych dla narodowej mitologii elementów zaznaczyłyby się zapewne znacznie wcześniej ${ }^{13}$, chociaż na temat ich charakteru i zakresu trudno spekulować.

Ogólnie rzecz biorąc, nie jesteśmy zapewne bardziej racjonalni od naszych przodków sprzed kilku pokoleń; przeniesieni w nasze czasy mieliby oni zapewne nie mniejsze kłopoty ze zrozumieniem naszych poczynań niż my z ich oceną. Bez próby zmniejszenia owego dystansu będziemy mieć zasadnicze kłopoty ze zrozumieniem motywacji podejmowanych przez nich działań - również tych o tak zasadniczym znaczeniu, jak decyzja z 1939 r. Rekonstrukcja debaty publicznej, jak i świadectw prywatnych (korespondencja, diariusze) stwarza możliwość złagodzenia problemu.

\section{JEZYK ALUZJI JAKO INSTRUMENT DEBATY}

Myśl polityczna nie powstaje w próżni. Dlatego też składających się na nią enuncjacji -poczynając od dzieł książkowych, zawierających próby formułowania szerszych założeń doktrynalnych, poprzez programy stronnictw, aż po zawarte $\mathrm{w}$ prasie oraz drukach zwartych uzasadnienia tychże (bądź dyskusje toczące się na marginesie sporów o sprecyzowanie stanowiska $w$ takiej czy innej kwestii) -w ogóle nie można rozpatrywać w oderwaniu od jej tła tworzonego przez realia polityczne czy społeczne. W grę wchodzi tu mnóstwo zależności różnego rodzaju, od oddziaływania pośredniego wydarzeń, zjawisk, mód intelektualnych, panujących nad zbiorową wyobraźnią generacji, po incydentalne zdarzenia o relatywnie niewielkim zasięgu i wadze, ale powiązanych ściśle akurat z daną enuncjacją, która stanowi do niej komentarz, albo też staje się w pełni zrozumiała dopiero w roli komentarza, nie zawsze wypowiadanego expressis verbis. Nieuwzględnienie owego kontekstu może prowadzić do szkolnych błędów.

Przykładowo, jeden z bardziej zjadliwych komentarzy na temat Polski lat trzydziestych nosił tytuł Hellada na przełomie -biorąc pod uwagę zarówno jego tytuł, zawartość, jak i pamiętając o tym, że autor eseju, profesor Stanisław Łoś, był historykiem starożytności, równie dobrze można byłoby go uznać za formę popularyzacji wiedzy. Tyle że „dobrze” oznaczałoby w tym wypadku koncentrację na formie przekazu, przy uznaniu za nieistotne intencji przyświecających autorowi.

Tego rodzaju przykłady prób objaśniania współczesnych problemów politycznych przez odwoływanie się do przeszłości można mnożyć. Czasem, jak w latach siedemdziesiątych i osiemdziesiątych XX stulecia pozorna ucieczka w historię stanowiła po prostu sposób omijania barier politycznych - w tym cenzuralnych - stwarzając okazję rozmawiania o współczesnych problemach w sposób dla autora komfortowy, zapewniający mu bezpieczeństwo, przy dużej dozie pewności, że jego przekaz dotrze do nawykłych do czytania pomiędzy wierszami odbiorców. Czasem jednak (bardzo często przed 1939 r.) podobny zabieg wynikał po prostu z przekonania, że historia jest nauczycielką życia i jeśli na marginesie współczesnych problemów przypomni się ich przeszłość, to tego rodzaju analiza uzyska walor ogólności. Nie tylko wyjaśni, co może nas czekać i co należy czynić, ale i wskaże ogólną prawidłowość, rządzącą podobnymi sytuacjami od dawna, jeżeli nie od zawsze. To dlatego głośne traktaty politycznoideologiczne lat trzydziestych: Kazimierza Mariana Morawskiego, Jędrzeja Giertycha,

\footnotetext{
${ }^{13} \mathrm{~W}$ pewnej mierze poniekąd pojawiły się, mimo systemowych ograniczeń: dość przypomnieć szkołę polską w filmie, czy - po drugiej stronie - publicystyczne boje Zbigniewa Załuskiego, starającego się zaadaptować do potrzeb PRL część dawnej heroicznej mitologii.
} 
Adolfa Bocheńskiego ${ }^{14}$, miały formę rozpraw historycznych. Dwaj pierwsi ostrzegali przed spiskami ze strony masonerii oraz Żydów, Bocheński (w odróżnieniu od pozostałych wymienionych postrzegany obecnie jako postać niekontrowersyjna) piętnował bierność polityki zagranicznej dawnej Polski jako przyczynę jej późniejszych problemów. Wszyscy wszakże podobni byli do siebie w tym, że maksymę „Historia magistra vitae est" rozumieli najzupełniej dosłownie; przeszłości nie traktowali jako już dokonanej, w żadnym też z przywoływanych przypadków nie była ona czymś więcej niż medium ułatwiającym zrozumienie potrzeb współczesności. Punktem odniesienia dla historycznych analiz oraz właściwym ich tłem były więc wewnętrzne oraz zewnętrzne problemy Polski lat trzydziestych. Dla współczesnych autorom czytelników tego rodzaju przekazów jasne było, że są one komentarzem do współczesności, a nie wykładem o zamkniętej już przeszłości.

Podobnie pretekstowe, co najmniej zaś zdeterminowane sytuacją lokalną, polską bywały także oceny bieżących wydarzeń, dokonujących się w bliższym i dalszym sąsiedztwie naszego kraju. W swoim czasie miałem okazję zwrócić uwagę na właściwości komentarzy publikowanych w prasie endeckiej, a odnoszących się do sytuacji w III Rzeszy. Ich apogeum przypadło na okres rozłamów, dokonujących się w obozie narodowym, później, sądząc z liczby tekstów, a także wyraźnego obniżenia się temperatury ocen, zainteresowanie osłabło ${ }^{15}$. Jakkolwiek można wskazywać, że było to nieuniknione, gdyż wraz ze stabilizacją systemu władzy ruch nazistowski stał się mniej „,medialny” niż w dobie marszu po władzę, sygnalizowany wcześniej doraźny kontekst komentarzy był prawdziwy.

Wielce pouczająca może być lektura wspomnień jednego z endeckich secesjonistów, Jerzego Drobnika. Na jej podstawie można stwierdzić (a jako korespondent endeckiego „Kuriera Poznańskiego” przebywał w Berlinie i mógł obserwować sytuację na miejscu), że był on krytyczny wobec nazizmu, obserwował jego postępy z obawą; miał także kontakty z przeciwnikami reżimu. Natomiast, gdy czyta się jego pisane na bieżąco komentarze, aż trudno pojąć, jak możliwe było takie rozdwojenie jaźni. Jeśli wszakże rozumieć je przez pryzmat sytuacji w obrębie środowiska, do którego należał Drobnik, przekaz stanie się bardziej zrozumiały. Na przykład podkreślanie zalet ruchu, który nie chciał być ,jedynie taranem" starszego pokolenia nacjonalistów - dlatego ich obawy przed ryzykiem nie ograniczyły jego dynamizmu. W interpretacji Drobnika kluczem do sukcesu hitlerowców było nie tylko odwołanie się do haseł narodowych, ale właśnie odsunięcie od wpływów działaczy w podeszłym wieku... Argumenty te były obliczone na polskiego czytelnika identyfikującego się $\mathrm{z}$ ideami głoszonymi przez Narodową Demokrację, ale zniechęconego brakiem perspektyw przejęcia przez nią władzy. Były one skądinąd niezgodne z linią redakcji macierzystego dziennika, gdzie przeważały poglądy liberalne.

Casus Drobnika odzwierciedlał szerszą prawidłowość, wykraczająca daleko poza ramy jego środowiska politycznego oraz jego czasów. Czy - na przykład - dominujące w

\footnotetext{
${ }^{14}$ A. Bocheński, Między Niemcami a Rosją, Warszawa 1937; J. Giertych, Tragizm losów Polski, Pelplin 1936; K.M. Morawski, Źródto rozbiorów Polski. Studia i szkice z ery Sasów i Stanistawów, Warszawa 1935

${ }^{15}$ K. Kawalec, Spadkobiercy niepokornych. Dzieje polskiej myśli politycznej 1918-1939, Wrocław 2000, s.200; idem, Narodowa Demokracja wobec nacjonalizmu niemieckiego, „Dzieje Najnowsze” $1986 / 3-4$, s. 154
} 
pismach prorządowych tamtego czasu opinie podnoszące zalety jednoosobowego kierownictwa oraz silnej władzy, a ilustrowane przykładami Włoch, Niemiec czy kemalistowskiej Turcji, rzeczywiście odnosiły się do sytuacji w tamtych krajach, nie były zaś formą odpowiedzi na argumentację typu wolnościowego, do której sięgała opozycja ${ }^{16}$ ? Jakkolwiek istnienie tego rodzaju uwarunkowań wydaje się bezsporne, z punktu widzenia historyka myśli politycznej oznaczają one kłopoty, zmuszając ich do czytania między wierszami - co zawsze jest czynnością dyskusyjną i obarczoną ryzykiem błędu. Nie zawsze bowiem wchodzące $w$ grę zależności są oczywiste, łatwe do wyśledzenia. Konieczne jest również rozszerzenie skali kwerend poprzez uwzględnienie komentarzy pozornie odległych od tematu badawczej penetracji. Jeśli bowiem zdarza się, że interesujące nas, istotne dla tematu penetracji badawczej treści znaleźć można także w komentarzach poświęconych pozornie odległej tematyce, to nie ma innej rady - trzeba czytać wszystko.

\section{BŁECY UŚREDNIENIA}

Kwestią o zasadniczej wadze jest interpretacja opinii wyrażanych przez polityków oraz ideologów. Truizmem jest stwierdzenie, że dla polityka słowo, zwłaszcza wypowiadane publicznie, stanowi instrument działania. Jeśli jednak jest ono instrumentem, to czy można traktować je po prostu jako wyraz jego wewnętrznego przekonania, kojarzyć z innymi opiniami zbliżonymi co do tematyki albo dotyczącymi spraw odleglejszych po to, aby w tworzonej syntezie powiązać je w spoisty system, jakoby charakteryzujący poglądy postaci?

A zdarza się - znam sporo tego rodzaju prac - że podobny zabieg dotyczy nawet nie poszczególnych postaci, ale całych, często rozległych środowisk, obejmując enuncjacje wygłaszane $\mathrm{w}$ różnych okolicznościach przez rozmaitych ludzi, o różnych poglądach i różnym stopniu zaangażowania w działalność własnego środowiska, wiązanych $\mathrm{z}$ sobą przez badacza w spójną narrację z użyciem słów „,wskazywano”, „uważano”, „zwracano uwagę". W wyniku takiego zabiegu poglądy w obrębie środowiska ulegają pewnego rodzaju wygładzeniu. Może być ono w niektórych wypadkach pożądane, tam gdzie zależy nam na odpowiedzi na pytania ogólnej natury, wywód nie gubi elementarnych zależności przyczynowo-skutkowych ${ }^{17}$, a podstawą dla uogólnień są poglądy rzeczywiście dominujące - nie powinno jednak odbywać się to kosztem przeoczenia istotnych szczegółów obrazu.

\footnotetext{
16Patrz: „Zaczyn” z czerwca 1937, numery 22 i 24. W interpretacji publicystów podpisujących się numerami (141) i (17) przyjęcie ustroju dyktatorskiego gwarantowało krajowi awans na arenie międzynarodowej. Patrz też : F.Goetel, Podznakiem faszyzmu, Warszawa 1939, s. 15, 211-212. Do tej konwencji sięgała także opozycja. Abstrahując tu od mitu „międzynarodowego faszyzmu”, którym operowały środowiska penetrowane przez III Międzynarodówkę, epitet „faszyzmu” bywał także selektywnie stosowany, kojarzony z praktykami państwa policyjnego -przykładem mogła być broszura Kazimierza Czapińskiego, Faszyzm wspótczesny (Warszawa 1932). Na pewno jednak w zdecydowanie mniejszym stopniu te publicystyczne zabawyodnosiły się do Italii Mussoliniego.

${ }^{17}$ Dzieje się tak wtedy, kiedy w wywodzie łączy się kwestie, których wzajemne związki są mało prawdopodobne lub nawet niemożliwe: taki stan rzeczy zachodzi, gdy badacz używa w narracji słowa „dlatego”, a zjawisko lub wydarzenie przedstawione przezeń jako „skutek” wyprzedzają w czasie jego rzekomą ,przyczynę”. Zdarzyło mi się niedawno recenzować pracę, gdzie podobna ułomność występowała nagminnie; podejrzewam, że w formie incydentalnej podobne lapsusy trafiają się częściej.
} 
Mam tu na myśli ryzyko utraty z pola widzenia zarówno różnic poglądów w obrębie badanego środowiska, jak i ich dynamiki: szczególnie zmian, jakie dokonywały się pod wpływem rozmaitych impulsów (co się łatwo może zdarzyć przy stosowaniu rzeczowego kryterium podziału materiału). Bywało także, że wypracowywanie określonego stanowiska było wynikiem rozłożonego na lata procesu - i wcale nie jest powiedziane, że przedstawienie tego stanowiska jest ważniejsze niż analiza przebytej drogi. Jeśli myśl polityczna stanowi swego rodzaju zapis publicznej debaty, dokonywanych na różnych poziomach $\mathrm{i}$ w obrębie różnych struktur, to $\mathrm{w}$ jej poznawaniu nie można się jedynie ograniczać do opisu danego stanowiska w jego wersji ostatecznej, bez uwzględnienia procesu jego krystalizowania się, jego etapów, a także rządzących nim mechanizmów.

Jeśli, na przykład, charakteryzując endecką koncepcję polityki zagranicznej, powiemy, że była ona antyniemiecka i prorosyjska, to będzie to skrót myślowy, dopuszczalny jedynie na bardzo wielkim poziomie ogólności. Jeśli uznać za nieistotne zaznaczające się równolegle w publicystyce, a także prywatnych wypowiedziach przejawy podziwu dla niemieckiej organizacji oraz polityki, to trudniej przejść do porządku dziennego nad tym, że w realiach międzywojennych także środowiska orientujące się wcześniej na Niemcy dystansowały się od polityki republiki weimarskiej, później zaś (tym bardziej) III Rzeszy. Antyniemieckość stanowiła zatem raczej właściwość polityki prowadzonej przez państwo generalnie zainteresowane w utrzymaniu porządku powersalskiego. W wypadku Rosji skala komplikacji jest większa przede wszystkim ze względuna konsekwencje rewolucji z listopada 1917 r. Na tle innych środowisk prawica, w tym endecja, wyróżniała się antykomunizmem; inną sprawą jest to, że próbowała godzić swoje stanowisko $\mathrm{z}$ uzasadnianiem postawy zajętej podczas I wojny światowej $\mathrm{i}$ w jej przededniu ${ }^{18}$. W wypadku ocen orientacji na Rosję błędem jest niedocenianie oporów, jakie w obrębie Ligi budziła taka polityka ${ }^{19}$, przede wszystkim jednak niedostrzeganie jej drugiego dna. Był to przykład sytuacji, w której cele polityki, sprecyzowane kilkanaście lat wcześniej, były ukrywane, ujawniane etapami, stosownie do okoliczności, a następnie bronione w swojej integralnej postaci - także w sytuacji pozornie pozwalającej na zupełną swobodę ruchów.

\section{PRZEKAZY UKRYTE}

Przypadek polityki prowadzonej podczas I wojny światowej przez Dmowskiego (a odnieść go można także do poczynań Józefa Piłsudskiego) jest interesujący właśnie jako ilustracja możliwości prowadzenia polityki wielotorowej, w której deklaracje składane oficjalnie nie odpowiadają realnym poczynaniom, a tym bardziej intencjom. Dlatego też w zależności od źródeł, do których sięgamy (oficjalne enuncjacje, stanowisko zajmowane

\footnotetext{
${ }^{18}$ Przymiotnik ,prorosyjski” także w tamtym zresztą wypadku wprowadza w błąd, sugerując zbieżność formułowanych celów politycznych z poczynaniami Rosji. Sformułowana w początkach lat siedemdziesiątych teza Romana Wapińskiego ( $Z$ dziejów tendencji nacjonalistycznych. O stanowisku Narodowej Demokracji w latach 1893-1939, „Kwartalnik Historyczny” 1973/4, s. 830) uzyskała potwierdzenie w materiałach dostępnych od niedawna. W wypadku będącego kluczową tu postacią Dmowskiego wskazać tu można na przechowywaną w warszawskim Muzeum Niepodległości korespondencję, która wpływała doń w kluczowych latach 1915-1920. Interesującym zapisem antyrosyjskich fobii Dmowskiego są opublikowane kilka lat temu zapiski pamiętnikarskie brytyjskiego dziennikarza, Roberta Villona (E.J.Villon, Spotkania, rozmowy i korespondencja z Romanem Dmowskim 1917-1922, „Glaukopis” 2006/5-6, s. 7-63).

${ }^{19}$ Zob. A.Juzwenko, Rosja w polskiej myśli politycznej lat 1864-1918, [w:]Polska myśl polityczna XIX i XX wieku..., s.58-61.
} 
w obrębie ścisłego grona współpracowników, rozważania publicystyczne, korespondencja, świadectwa osób mu bliskich), wyłaniający obraz może się różnić w istotnych szczegółach.

„Rekonstruując całość koncepcji, powinniśmy w każdym wypadku starać się oddzielić jej fasadę od tego, co stanowiło refleks systemu wartości. Skądinąd historyk starający się odtworzyć poglądy publicystów i ideologów jest i tak w sytuacji komfortowej ze względu na rozmiary pozostałej spuścizny pisarskiej, co daje możliwości selekcji wątków bardziej i mniej istotnych, śledzenia ich ewolucji, niekiedy także możliwych filiacji zewnętrznych - jeśli jesteśmy w stanie ustalić lektury bohatera, albo też określić, z czyimi poglądami w danym miejscu i momencie polemizuje.’Nie zawsze przecież jest tak, że postać poddawana analizie dostrzegała potrzebę utrzymywania kontaktu $\mathrm{z}$ politycznym elektoratem, pisząc wiele i w dodatku w zgodzie $\mathrm{z}$ podejmowanymi działaniami, a więc szczerze. Co jednak zrobić w sytuacji, gdy bohater jest konspiratorem z upodobania, nawyku i stylu działania i dopiero jego otoczenie interpretuje, czasem ex post, podejmowane decyzje. Czy są to miarodajne interpretacje? Jest to między innymi problem interpretacji poglądów Józefa Piłsudskiego, postaci kluczowej dla dziejów Polski pierwszej połowy XX stulecia. Jakkolwiek jego poczynania imponują rozmachem, nie można im też odmówić konsekwencji, można też wskazać na wspólny - co odnosi się także do środowisk uznających autorytet Pierwszego Marszałka -ich mianownik w postaci kategorii państwa ${ }^{20}$, uważanej za nadrzędną, istnieją jednak wciąż zasadnicze problemy ze spójną interpretacją wszystkich decyzji Piłsudskiego ${ }^{21}$, ryzyko błędu jest duże, a formułowane wnioski pozostaną w sferze lepiej lub gorzej udokumentowanych hipotez.

Sygnalizowane trudności są odbiciem szerszego problemu. Niestety, nie istnieje probierz pozwalający na ocenę szczerości enuncjacji polityków. Na szczęście nie musimy wyrokować w tej delikatnej materii. Nawet bowiem całkowicie cyniczna, nieoddająca poglądów postaci wypowiedź (załóżmy, że się takie przypadki niekiedy w odległych czasach zdarzały) zasługuje na uwagę. Nawet jeśli nie zawsze informuje o rzeczywistych poglądach twórcy przekazu, to jednak wiele mówi o oczekiwaniach jego odbiorców. Jest zatem interesująca dla badacza, a jej analiza może się obyć nawet bez wątpliwych prób psychologizowania i rozstrzygania kwestii, w których wyrokować nie sposób. Konieczne natomiast jest uważne śledzenie wszystkich istotnych kontekstów enuncjacji, jej uwarunkowań ${ }^{22}$, precedensów (jeśli były), a także ewentualnych skutków, pozwalających wyrobić sobie opinię o jej rzeczywistej wadze.

${ }^{20}$ Zob. W. Paruch, Myśl polityczna obozu pitsudczykowskiego, Lublin 2005;W.T.Kulesza, Koncepcje ideowo-polityczne obozu rzadzacego w Polsce w latach 1926-1935, Wrocław 1985.

${ }^{21}$ Sam w końcu miewał z tym problemy, mówiąc w rozmowie z Arturem Śliwińskim o kilku postaciach składających się na jego psychikę, czasem zgodnych w opinii, czasem ze zmiennym powodzeniem walczących z sobą (A.Garlicki, OdBrześcia do maja, Warszawa 1986, s. 162-163).

${ }^{22}$ Naturalnie uwarunkowań bieżących, co oznacza śledzenie enuncjacji oraz wydarzeń równoległych lub wcześniejszych - chociaż zdarzyło mi się jakiś czas temu czytać pracę, w której nawet związki przyczynowo-skutkowe zostały zaburzone przez ilustrowanie enuncjacji późniejszymi wydarzeniami, przez wskazanie na nie jako przyczyny, determinujące określone stanowisko komentatora... 
Dla autora pionierskiej syntezy polskiej myśli politycznej XIX wieku Wilhelma Feldmana osią narracji były dzieje „,zmysłu niepodległości narodowej”, pomysłów na stworzenie „warunków własnego, samoistnego bytowania"23. Krystalizujące się u schyłku XVIII stulecia musiały walczyć o rząd dusz zarówno z wpływami obcymi, jak i z rodzimym kwietyzmem; ich tło stanowiły podejmowane uparcie próby ocalenia zagrożonej państwowości, później zaś jej przywrócenia; kolejny układ odniesień stanowiły współczesne im prądy ideowe, przyjmujące się (lub nie) na gruncie polskim, niejako oswajane $\mathrm{w}$ roli narzędzi ułatwiających zrozumienie świata oraz - z perspektywy zbiorowości -znalezienie skutecznych instrumentów przetrwania, ochrony kulturowego depozytu, a także walki o własne państwo w przyszłości. Synteza Feldmana wyrażała optykę ruchu niepodległościowego początku XX stulecia; ćwierć wieku później, gdy dawni spiskowcy i bojownicy o wolność mocno trzymali władzę, powołując się na nadrzędną wobec bieżących dążeń społeczeństwa ideę państwa, wymowa tej opowieści przestała być jednoznaczna. Z dążeń do niepodległości wcale bowiem nie wynikały sugestie co do tego, jak zorganizować własne państwo. Na kluczowe dla wielu czytelników książki w latach trzydziestych XX wieku pytanie, czy zasługi z przeszłości mogą uzasadniać dążenia do ustanowienia monopolu władzy, książka nie dawała odpowiedzi, jakkolwiek zawarta w niej wizja przeszłości, oceny poczynań poszczególnych środowisk politycznych - ogólnie rzecz biorąc - odpowiadała obozowi rządzącemu. Na innym poziomie i w rzetelniejszej postaci, podobnie jak publicystyka Władysława Poboga - Malinowskiego, książka stanowiła pokłosie sporu orientacyjnego; w realiach odrodzonej Polski w coraz większym stopniu anachronicznego. Trudno wciąż mówić o drodze do niepodległości we własnym państwie, w którym jednak pozostaje mnóstwo problemów do rozwiązania.

Z debatami lat dwudziestych i zwłaszcza trzydziestych jest inaczej - jako że znaczna część problemów dominujących wówczas w publicznych debatach zachowuje aktualność. Jakkolwiek współczesna Polska nie jest już państwem wielu narodowości i kwestie związane z ich aspiracjami i dążeniami, chociaż ważne, nie grożą już państwu niebezpiecznymi dlań komplikacjami, to wiele innych kwestii nadal wpływa na nasze życie zbiorowe. Dotyczy to zwłaszcza miejsca człowieka w społeczeństwie, granic wolności, roli przymusu wywieranego przez społeczeństwo poprzez instytucje państwa, a także inne struktury; relacji między światem pieniądza a światem pracy, możliwości realizacji prawa do zrzeszeń, granic pluralizmu - zarówno deklarowanych, jak i faktycznie zakreślanych -przez akceptację dialogu na partnerskich zasadach. Z tym wiąże się problem prawa do udziału $w$ obiegu informacji, a także technik ograniczających możliwości korzystania $\mathrm{z}$ tego prawa. Wciąż żywe wydają się kwestie związane $\mathrm{z}$ pojmowaniem prawowitości władzy państwowej, dopuszczalnego zakresu jej uprawnień, a także relacji między „Zwykłymi” obywatelami a grupą wyróżniającą się posiadanym majątkiem, prestiżem społecznym czy udziałem w sprawowaniu władzy ${ }^{24}$. Jakkolwiek moda na elitaryzm w kształcie $\mathrm{z}$ lat trzydziestych minęła, problem pozostaje w mocy, chociaż inaczej postrzegany i rodzący odmienne niż kiedyś niebezpieczeństwa (vide

\footnotetext{
${ }^{23}$ W. Feldman, Dzieje polskiej myśli politycznej 1864-1914,2 wyd., Warszawa 1933, s. 1.

${ }^{24}$ Rzecz jasna, także walorami ducha - w tym gotowością do walki nie tylko z obcą przemocą, ale i na froncie wewnętrznym, przeciw rodzimej bierności i bylejakości (Patrz Andrzej Wierzbicki, Naród-państwo w polskiej myśli historycznej dwudziestolecia międzywojennego, Wrocław 1978, s. 120-122).
} 
interesująca diagnoza Christophera Lascha ${ }^{25}$ ). Dotyczy to także stosunku do tradycji, w tym także instytucji z tą tradycją się kojarzących, przede wszystkim Kościoła.

Przynajmniej od końca XIX stulecia istnieje problem relacji między tak zwaną kulturą wysoką a kulturą masową. Rozwój tej ostatniej wpływał także na kształt i jakość debaty publicznej, budząc niepokój moralistów. Jakkolwiek znaczną część podnoszonych argumentów z perspektywy czasu można uznać za przesadną - umasowienie polityki było bowiem funkcją jej demokratyzacji i nawet prymitywizacja argumentacji nie powinna być oceniana negatywnie, jeśli przyczyniała się do rozszerzania kręgu środowisk poczuwających się do odpowiedzialności za własne państwo. W kontekście zagrożeń XX stulecia demokratyzacja polityki nie była zatem zapowiedzią katastrofy ${ }^{26}$, przeciwnie działała raczej na rzecz jej oddalenia. Piszę „raczej”, gdyż równolegle masowa kultura produkowała rozmaite medialne śmieci zatruwające publiczną debatę, narzucając wykrzywioną optykę w postrzeganiu świata: gdzie kwestie związane na przykład z polityka zagraniczną czy wewnętrzną schodziły na dalszy plan w obliczu wydarzeń prawdziwie niepokojących, takich jak niedyspozycja gwiazdy sportu albo kina. W połowie lat trzydziestych emocje w Polsce budził zarówno proces brzeski, jak i sprawa Gorgonowej; rozstrzygnięcie, czy zaznaczały się w ten sposób dokonujące się żywiołowo przeobrażenia o charakterze globalizacyjnym, czy była to tylko propagandowa manipulacja obozu rządzącego -zainteresowanego w absorbowaniu uwagi opinii publicznej głupstwami w oczywistej intencji uchronienia jej od trudu zadawania sobie kłopotliwych pytań- stanowiłoby interesujące przedsięwzięcie badawcze. Trudno powiedzieć, czy powstała książka mogłaby liczyć na odbiorców na tak spustoszonym rynku czytelniczym jak obecny, natomiast z poznawczego punktu widzenia określenie rozmiarów wpływu różnych wątków pobocznych na kształt publicznej debaty byłoby przedsięwzięciem pozwalającym wiele się dowiedzieć i wiele zrozumieć.

Istotne jest więc, aby badacz uważnie wsłuchiwał się w puls debaty publicznej sprzed lat $^{27}$, poprzedzając formułowanie wniosków uprzednim upewnieniem się, co interesowało ludzi, jak postrzegali świat i w jaki sposób wyrażali swoje myśli. Jakkolwiek nadmierna empatia kryje w sobie oczywiste niebezpieczeństwa, więcej problemów wiąże się raczej z tendencją do aroganckiego narzucania własnej miary wartości i własnych pojęć. Jeśli potrafimy zrozumieć ludzi rozwijających swą aktywność w innym od naszego czasie,

${ }^{25}$ Ch.Lasch, Bunt elit, Kraków 1997.

${ }^{26}$ Zob. F.Znaniecki, Upadek cywilizacji zachodniej. Szkic z pogranicza filozofii kultury i socjologii, Poznań 1921.

${ }^{27}$ Niestety, wiele wskazuje na to, że mimo sygnalizowanych problemów i trudności będzie on i tak w o wiele lepszej sytuacji niż badacze, którzy za lat kilkanaście lub kilkadziesiąt będą próbowali rekonstruować polityczną debatę czasów nam współczesnych. Znacząca jej część odbywa się za pośrednictwem mediów elektronicznych, w tym takich (portale społecznościowe, blogi, posty pod komentarzami prasowymi, korespondencja elektroniczna), których zawartość nie jest przechowywana w sposób trwały. Obecnie jedno polecenie administratora sieci kasuje treści, które jeszcze niedawno pozostawały na papierze i po latach, przynajmniej w części, mogły być dostępne dla badaczy. Potrzeba instytucji, zbierającej i dokumentującej tego rodzaju świadectwa, wydaje się oczywista. Wiąże się to oczywiście z pewnymi trudnościami: szukanie odpowiedzi na pytania, takie jak jakich środków wymagałaby tego rodzaju działalność, jak prowadzić ją z uszanowaniem prawa prywatności, a także jak wyeliminowanie ryzyka nadużywania podobnych informacji do celów niemających nic wspólnego z nauką. Jest to duży problem. 
będziemy w stanie nie tylko przekazać płynące od nich przesłanie, ale także - analizując zachowania oraz mechanizmy -dowiedzieć się czegoś więcej także o sobie.

\section{LITERATURA}

[1] Bocheński A., Między Niemcami a Rosja, Warszawa 1937.

[2] Colbern W.H., Polska. Styczeń -sierpień 1939. Analizy i prognozy. Komentarze do wydarzeń attache wojskowego ambasady USA w Warszawie, Warszawa 1986.

[3] Feldman W., Dzieje polskiej myśli politycznej 1864-1914,2 wyd., Warszawa 1933, s. 1.

[4] Garlicki A., Od Brześcia do maja, Warszawa 1986.

[5] Giertych J., Tragizm losów Polski, Pelplin 1936.

[6] Goetel F., Podznakiem faszyzmu, Warszawa 1939.

[7] Hertz A., Żydzi w kulturze polskiej, Paryż 1961.

[8] Juzwenko A., Rosja w polskiej myśli politycznej lat 1864-1918, [w:]Polska myśl polityczna XIX i XX wieku.

[9] Kawalec K., Spadkobiercy niepokornych. Dzieje polskiej myśli politycznej 19181939, Wrocław 2000.

[10] Kulesza W.T., Koncepcje ideowo-polityczne obozu rzadzacego w Polsce w latach 1926-1935, Wrocław 1985.

[11]Casch Ch., Bunt elit, Kraków 1997.

[12]Morawski K.M., Źródto rozbiorów Polski. Studia i szkice z ery Sasów $i$ Stanistawów, Warszawa 1935.

[13]Narodowa Demokracja wobec nacjonalizmu niemieckiego, „Dzieje Najnowsze” 1986/3-4.

[14]Paruch W., Myśl polityczna obozu pitsudczykowskiego, Lublin 2005.

[15] Villon E.J., Spotkania, rozmowy i korespondencja z Romanem Dmowskim 19171922, „Glaukopis” 2006/5-6.

[16]Wapiński R., Świadomość polityczna w II Rzeczypospolitej, Łódź 1989.

[17]Wata A., Mój wiek. Pamiętnik mówiony. Część pierwsza, Warszawa 1990.

[18]Wierzbicki A., Naród-państwo w polskiej myśli historycznej dwudziestolecia międzywojennego, Wrocław 1978.

[19]Zaczyn" z czerwca 1937, numery 22 i 24.

[20]Zieliński H., Stowo wstępne, [w:]Polska myśl polityczna XIX $i \quad X X$ wieku,t.1:Polska i jej sąsiedzi, red. H.Zieliński, Wrocław 1975.

[21]Znaniecki F., Upadek cywilizacji zachodniej. Szkic z pogranicza filozofii kultury $i$ socjologii, Poznań 1921.

\section{POLITICAL THOUGHT - A MIRROR OF SOCIAL ASPIRATIONS AND DESIRES. SCIENTIFIC OPPORTUNITIES (AND BENEFITS), LIMITATIONS, BARRIERS, PITFALLS}

For a historian, the reason to research political thought is basically to expand the range of questions that, when answered, allow the past - including key occurrences and processes -to be explained more fully and with greater precision. If we determine how people used to think, we will understand how they behaved and why. A shortcoming commonly encountered in many attempts at reconstructing the past is the seemingly obvious, but nonetheless erroneous assumption that the basic rationality remains constant, and that people living in past times thought similarly to how we do today. This is especially 
prevalent in contemporary history, due to the impression that the times we are trying to describe are essentially present-day. However, this impression may be wrong: even the set of terms and expressions used in colloquial communication changes significantly each 10-15 years. In the case of far-reaching changes in the political and social situation the matters complicate further, and the probability of a significant error being committed by a researcher increases significantly.

This is especially true in attempts to reconstruct a public debate. Even when having material traces of such a debate at our disposal (correspondence, diaries, programs of political parties, polemics, and most importantly the printed press) we can misunderstand their message (or at least not understand it fully) as long as we simply consider them as expressions of views, separated from their context or their current situation. Interpretations of public speeches (including commentaries) of politicians and ideologists are particularly affected by this. The statement that, for a politician, words are a tool of action rather than of sharing their thoughts is a truism. The situation surrounding a politician's actions forms a background to their words spoken publicly. In many cases it is the deciding factor of not just the content, but the form of the speech as well. Those were (and still are) different. A politician sometimes comments on the situation openly, sometimes with an allusion, and sometimes, believing that "historia magistra vitae est", through a mention of past events. In that last case, however, it is the current situation, and not the distant past, that is usually used as a reference for its interpretation.

It is obvious that all these nuances must be taken into consideration when reconstructing the views of either a person or a community. In case of communities it is vital to describe the mainstream views as well as the extremes, considering their evolution and all the individual differences that reflect how ideas varied within a movement. A defect found in many studies on the subject is to take the "average" of sorts from all the views found within a researched environment through blurring the differences and exposing how a doctrine's elements bonded with each other rather than how they were related to their surroundings and the evolving political situation.

Keywords: political thought, contemporary history, public debate, social aspirations and desires, research difficulties.

\section{DOI:10.7862/rz.2015.hss.50}

Przesłano do redakcji: listopad 2014

Przyjęto do druku: grudzień 2015 